\title{
ПРОБЛЕМА «МНИМЫХ ДРУЗЕЙ ПЕРЕВОДЧИКА» В МЕЖКУЛЬТУРНОЙ КОММУНИКАЦИИ
}

\author{
О. Н. Мальцева, Ю. А. Монашева \\ Московский гуманитарный университет
}

\begin{abstract}
Аннотация: В статье рассматривается роль межъязыковой омонимии в межкультурной коммуникации на примере лексических единиц, часто встречающихся в содержании дисциплин «Иностранный язык» и «Иностранный язык в профессиональной сфере» на различных направлениях обучения в Московском гуманитарном университете. Подчеркивается необходимость уделять данному явлению большее значение как фактору, который может препятствовать эффективному общению в современном глобальном мире.
\end{abstract}

Ключевые слова: межъязыковая омонимия; мнимые друзья переводчика; межкультурная коммуникация; лингвистический шок; проблемы перевода

\section{THE ISSUE OF «FALSE FRIENDS» IN INTERCULTURAL COMMUNICATION}

\author{
O. N. Maltseva, Yu. A. Monasheva \\ Moscow University for the Humanities
}

\begin{abstract}
The article looks at the role of cross-lingual homonymy in intercultural communication exemplified by lexical units often seen in the curricula of disciplines «Foreign language» and «Foreign language in the professional sphere» in various courses of study at Moscow University for the Humanities. The authors emphasize the importance of paying closer attention to the given phenomenon as a factor that can impede effective communication in today's global world.
\end{abstract}

Keywords: cross-lingual homonymy; false friends; intercultural communication; linguistic shock; problems of translation

В данной статье речь пойдет о сложном аспекте межкультурной коммуникации, которому не всегда уделяют достаточно внимания на занятиях английского языка: межъязыковая омонимия (мнимые друзья переводчика). С развитием информационных технологий, ростом числа туристических поездок, международных конференций и программ зарубежного образования остро встает вопрос о терпимости и уважении к чужим культурам. Усиление роли нашей страны на международных и европейских форумах, расширение культурных, экономических и научных связей с зарубежными 
странами требует формирования у учащихся гуманитарных вузов уверенных навыков межкультурной коммуникации.

Межкультурную коммуникацию можно определить как взаимодействие между представителями различных национальных культур, которое, в контексте XXI века с его интернет-технологиями и новыми формами общения, становится абсолютно необходимым для существования человека в современных условиях. Нельзя не согласиться с мнением американского врача, поэта и писателя О. У. Холмса, что язык имеет важнейшую функцию хранителя культуры: «Каждый язык - это храм, в котором бережно хранятся души говорящих на этом языке». Это вовсе не означает, что собеседники, представляющие разные культуры, не смогут понять друг друга. Но для построения эффективной коммуникации крайне важно понимать культурные особенности ее участников.

Английский язык, играющий в современным мире роль международного, представляет множество трудностей как для самих носителей, так и для изучающих его. Первая, и наиболее очевидная сложность - орфография. Нельзя не упомянуть и отсутствие рода и склонения у существительных, а отсутствие привычного для многих носителей европейских языков спряжения глаголов, на наш взгляд, не упрощает овладение языком, а наоборот, усложняет его. В ходе работы преподаватели английского языка неоднократно сталкивались с непониманием и неприятием некоторых грамматических и лексических явлений со стороны обучающихся.

Преподаватели иностранных языков и культурологи нередко сталкиваются с понятием культурного шока как состояния удивления учащегося или даже неприятия им культурных фактов изучаемого языка. В межкультурной коммуникации существует еще одно явление - лингвистический шок. Это состояние удивления или смущения, возникающее тогда, когда при общении с носителем того или иного иностранного языка некоторые элементы речи говорящего кажутся слушающему смешными, нелепыми или даже неприличными. Сюда же можно и отнести феномен межъязыковой омонимии («ложные или мнимые друзья переводчика»), с которым сталкиваются обучающиеся при переводе с английского языка на русский и наоборот.

Мнимые друзья переводчика часто приводят к неправильному пониманию и переводу текста. Часть из них образовалась из-за того, что после заимствования значение слова в одном из языков изменилось, в других случаях заимствования вообще не было, а слова происходят из общего корня в каком-то древнем языке, но, несмотря на частичное или полное созвучие, имеют разные значения. Лингвисты обнаружили межъязыковую омонимию, проведя детальное исследование и изучение данного явления. Тер- 
мин «ложные друзья» был введен М. Кесслером и Ж. Дероккиньи в 1928 г. в книге «Les faux amis ou Les trahisons du vocabulaire anglais» («Ложные друзья переводчика или ловушки английской лексики») (Koessler, Derocquigny, 1928). Были созданы словари, включающие в себя подобного рода слова, а также их верный и ошибочный перевод. В 1969 г. был опубликован двуязычный словарь (англо-русский и русско-английский) «ложных друзей переводчика» украинского лингвиста, доктора филологических наук В. В. Акуленко, насчитывающий 900 английских слов (Акуленко, 1969). К каждому слову прилагается похожее по звучанию русское слово и их анализ несоответствия, полного или частичного. Прошедшие с тех пор десятилетия потребовали нового подхода к мнимым друзьям переводчика. Появились справочники и учебные пособия, посвященные этой проблеме, например, А. И. Пахотин опубликовал «Словарь мнимых друзей переводчика» (Пахотин, 2003). В 2004 г. появился англо-русский словарь ложных друзей переводчика, автором которого является К. В. Краснов (Краснов, 2004). Он насчитывает уже 1000 англо-русских мнимых друзей, и этот список будет пополняться.

Причин, приводящих к подобным ошибкам, несколько: это и убежденность говорящего в том, что слова и грамматические формы в разных языках равнозначны («я боюсь» могут переводить на английский как «I afraid», считая прилагательное «afraid» глаголом по аналогии с русским языком), и смешение графического облика слов, и неумение подобрать подходящее русское значение для перевода английских слов и грамматических конструкций.

Рассмотрим несколько примеров межъязыковой омонимии, часто встречающихся в учебных пособиях, используемых в рамках преподавания дисциплин «Иностранный язык» (по программам подготовки бакалавриата) и «Иностранный язык в профессиональной сфере» (по программам подготовки магистратуры) на факультете экономики, управления и международных отношений, факультете культуры и искусства, а также на юридическом факультете Московского гуманитарного университета. Ниже представлен краткий список так называемых «легких» слов, которые, по наблюдению авторов, почти всегда вызывают неизбежные ошибки при переводе.

1. Advocate ошибочно переводить как адвокат, хотя в английском оно прежде всего означает сторонника какой-то идеи. Адвокат следует переводить как lawyer, attorney, barrister, solicitor.

2. Appellation могут ошибочно переводить как апелляция, хотя в английском это слово означает присвоение имени, наречение. Апелляция следует переводить как appeal.

3. Argument не всегда стоит переводить как аргумент. В английском 
языке это слово в первую очередь означает спор, ссору. Аргумент рекомендуется переводить как reason, point, grounds.

4. Codex могут ошибочно переводить как кодекс, хотя в английском языке оно означает древнюю рукопись. Кодекс следует переводить как соде.

5. Corpus может ошибочно переводится как корпус, хотя его основное значение - свод (законов); антология. Корпус следует переводить на английский язык как body, torso (тело); body, frame (корпус машины или механизма); hull (корпус корабля); building (корпус здания).

6. Parole очень часто ошибочно переводят как пароль, хотя это слово означает условно-досрочное освобождение. Пароль следует переводить на английский язык как password.

7. Deputy чаще всего переводится как заместитель руководителя, и только во втором значении депутат.

8. Expertise может ошибочно переводиться на русский язык как экспертиза, хотя в английском языке оно означает профессиональную компетенцию, специальные знания и навыки, глубокие познания. Экспертиза следует переводить на английский язык как expertexamination, assessment, evaluation.

9. Caucasian в английском языке прежде всего означает человека европеоидной расы со светлым цветом кожи, поэтому Кавказец (выходец из района Кавказских гор) во избежание недопонимания следует переводить как а person from the Caucasus / a native of the Caucasus.

10. Bazaar в английском языке означает восточный базар, а не колхозный рынок. Базар (рынок) следует переводить на английский язык как market, open-air market.

11. Anecdote следует переводить на русский язык в первую очередь как короткий рассказ, основанный на личном опыте. Анекдот переводится на английский язык словами јoke, funny story.

12. Dutch может ошибочно переводиться на русский язык как датский, хотя в английском языке оно означает голландский, голландец. Датский, датчанин переводится на английский язык как Danish.

13. Journal часто ошибочно переводят как журнал, хотя в английском языке оно прежде всего означает серьезное специализированное периодическое издание. Второе частотное значение - дневник (запись прошедших событий). Журнал переводится на английский язык как magazine.

14. Sympathy может ошибочно переводиться на русский язык как симпатия, хотя в английском языке оно в первую очередь означает жалость, сочувствие. Симпатия следует переводить на английский язык как liking, affection.

15. Replica очень часто переводят на русский язык как реплика, хотя в 
английском языке оно означает точную копию чего-либо. Реплика следует переводить как remark, reply, cue.

16. Roman может ошибочно переводиться на русский язык как роман, хотя в английском языке оно означает римский (относящийся к городу Риму). Роман следует переводить на английский как novel.

17. Receipt может ошибочно переводиться как рецепт, однако, это слово означает чек, квитанция об оплате. Рецепт имеет несколько вариантов перевода: prescription (медицинский), recipe (кулинарный).

18. Thesis в английском языке в первую очередь означает не тезис, а курсовую, дипломную или иную письменную работу для получения ученого звания или степени. Тезис следует переводить на английский язык как proposition, point, argument.

19. Dramatic в английском языке в первую очередь означает неожиданный, впечатляющий, удивительный, разительный, значительный. И только во вторую очередь оно имеет значение театральный, драматический.

20. Chef может ошибочно переводиться на русский язык как шеф, хотя в английском оно означает шефб-повара (фр. chef-de-cuisine). Его также часто путают со словом chief, которое означает главный, важный. Шеф следует переводить на английский язык как boss, patron.

И это лишь малая часть примеров, иллюстрирующих типичные ошибки студентов, обучающихся в неязыковом вузе. В этой связи нам представляется необходимым подчеркнуть роль информационной среды, культурного и коммуникационного пространства как факторов, позволяющих преодолеть враждебность и непонимание между представителями различных культур. Задачей каждого преподавателя, таким образом, является создание такой среды и методов, которые бы способствовали преодолению трудностей перевода. Например, нами рекомендуется составление методических материалов, посвященных проблеме омонимии, с пояснениями, примерами и упражнениями на перевод; также, следует уделить больше времени объяснению студентам методов работы со словарями разных типов.

\section{СПИСОК ЛИТЕРАТУРЫ}

Акуленко, В. В. (1969) Англо-русский и русско-английский словарь «ложных друзей переводчика». М. : Советская энциклопедия. 384 с.

Пахотин, А. И. (2003) Англо-русский, русско-английский словарь мнимых друзей переводчика. М. : Издатель Корева А. К. 128 с.

Краснов, К. В. (2004) Словарь ложных друзей переводчика. М.: Издательство Э.Ра. 80 с. 
Koessler, M., Derocquigny, J. (1928) Les faux amis ou Les trahisons du vocabulaire anglais. Paris, Vuibert. 387 c.

Дата поступления: 15.12.2019 2.

Мальцева Ольга Николаевна - доцент кафедры иностранных языков Московского гуманитарного университета. Адрес: 111395, Россия, Москва, ул. Юности, д. 5 Тел.: +7 (499) 374-75-92. Эл. адрес: bettiboo@yandex.ru

Монашева Юлия Андреевна - специалист Лингвистического центра, доцент кафедры иностранных языков Московского гуманитарного университета. Адрес: 111395, Россия, Москва, ул. Юности, д. 5 . Тел.: + 7 (499) 374-7592. Эл. адрес: yumonasheva@mosgu.ru

Maltseva Olga Nikolayevna, Associate Professor, Department of Foreign Languages, Moscow University for the Humanities. Postal address: 5, Yunosti St., Moscow, Russian Federation, 111395. Tel.: +7 (499) 374-75-92. E-mail: bettiboo@ yandex.ru

Monasheva Yuliya Andreevna, Manager, Language Center; Associate Professor, Department of Foreign Languages, Moscow University for the Humanities. Postal address: 5, Yunosti St., Moscow, Russian Federation, 111395. Tel.: +7 (499) 374-75-92. E-mail: yumonasheva@mosgu.ru

\section{Для цитирования:}

Мальцева О. Н., Монашева Ю. А. Проблема «мнимых друзей переводчика» в межкультурной коммуникации [Электронный ресурс] // Научные труды Московского гуманитарного университета. 2020. № 1. URL: http://journals.mosgu.ru/trudy/article/view/1122 (дата обращения: дд.мм.гг.). DOI: 10.17805/trudy.2020.1.3 